\title{
Envejecimiento natural y artificial para evaluar los tratamientos para impermeabilización del mármol
}

\author{
Natural and artificial ageing for evaluating \\ waterproofing treatments for marble
}

MARISA LAURENZI TABASSO (1), ANNA MARIA MECCHI (2)

ITALIA

Fecha de recepción: 9-XII-91.

\section{RESUMEN}

La exposición de muestras a envejecimiento artificial se lleva a cabo comúnmente para chequear la duración de las piedras naturales y artificiales y la eficacia de los productos usados para su cuidado. Las correlaciones entre el envejecimiento artificial y natural, sin embargo, no siempre se entienden bien principalmente porque el envejecimiento trata de simular, de una manera rápida pero sencilla, los efectos de las muchas causas que actúan en el ambiente natural.

En este estudio, muestras de mármol de las canteras de Carrara y Proconnesio, han sido tratadas con cuatro productos o mezclas de productos, para su impermeabilización y expuestos a envejecimiento artificial. Mientras, un juego análogo de piedras se exponía al exterior en el centro de la ciudad de Roma, por un período de dos años.

Se midieron diferentes parámetros físicos antes y después del envejecimiento y los resultados de la experiencia han permitido comparar los efectos producidos por los diferentes tipos de envejecimiento y de establecer las correlaciones entre ellos.

Para la evaluación de los productos de impermeabilización, los dos sistemas son muy parecidos, aunque dos años de envejecimiento natural han resultado ser algo más duros que 33 días de exposición a niebla salina, radiaciones UV $y$ ciclos de humedad-sequedad.

\begin{abstract}
$S U M M A R Y$
Exposure of samples to artificial ageing is commonly carried out to test the durability of natural and artificial stones and the effectiveness of products used for their conservation. Correlations between artificial and natural ageing, however, are not always well understood mainly because the former can only try to simulate, in a faster but simplified way, the effects of the many causes interacting in natural environments.
\end{abstract}

In the present study, marble samples from Carrara and Proconnesion quarries, were treated with four waterproofing products (or mixtures of products) and exposed to artificial ageing while an analogous set was exposed outdoor, in the town center of Rome for two years.

Several physical paramenters were measured before and after the ageing and the experimental results enabled us to compare the effects produced by the different types of ageing and to estimate the correlations between them.

As for the durability of the tested waterproofing products, the two systems are in good agreement even if two years of natural ageing resulted to be slightly more severe than 33 days of exposure to saline fog, to UV radiation and to wetting-drying cycles.
(1) Química. Directora del Laboratorio de Pruebas de Materiales. Istituto Centrale per il Restauro. Piazza S. Francesco di Paola 9, 00184 Roma - Italia.

(2) Química, Dirección actual: CNR: Istituto per la Conservazione delle Opere Monumentali c/o Dip. Scienza dei Materiali. Compresorio Dip. Scientifici dell'Universitá, Via Arnesano, 73100 Lecce - Italia.
(1) Chemist, former Director of the Laboratory for Testing Materials, Istituto Centrale per il Restauro, Piazza S. Francesco di Paola 9, 00184 Roma, Italy. Present address: ICCROM, via di S. Michele 13, 00153 Roma, Italy.

(2) Chemist, present address CNR: Istituto per la Conservazione delle opere Monumentali c/o Dip. Scienza dei Materiali, Comprensorio Dip. Scientifici dell'Universitá, Via Arnesano, 73100 Lecce, Italy. 


\section{INTRODUCCIÓN}

La eficacia de los productos usados para la conservación de piedras se evalúa comúnmente por medio de la medición de varios parámetros físicos de muestras tratadas y no tratadas, antes y depués de la alteración artificial. Esto permite acelerar el estudio de la durabilidad de los tratamientos y por eso reducir el tiempo de la experiencia.

La alteración artificial se lleva a cabo a través de ciclos, tales como el hielo-deshielo, la cristalización de sales, spray ácido, etc. Estos ciclos están encaminados a la simulación de los efectos de la exposición en el exterior, en una situación dada.

Sin embargo, el envejecimiento es un fenómeno muy complejo, en el cual es difícil individualizar todos los parámetros que actúan y sus importancias relativas por dicho motivo. El envejecimiento artificial puede apenas simular una condición real.

Sólo trata de reproducir, en una forma más sencilla, los efectos de los factores más importantes. Muchos estudios se han llevado a cabo para mejorar nulos conocimientos en este campo (Zender, Arnold, 1988) (Heiman, 1988), pero el problema todavía no tiene una solución satisfactoria.

En este estudio se hace una tentativa para comparar los efectos del envejecimiento natural con aquéllos del envejecimiento artificial sobre muestras de las mismas piedras no tratadas con los mismos productos impermeabilizadores, aplicados con la misma metodología.

Los resultados de la experiencia permiten una comparación de los efectos totales de los dos métodos de desgaste y un chequeo de la conducta de los tratamientos estudiados bajo las condiciones del campo. Todavía necesitamos un entendimiento más profundo de los mecanismos de alteración y de la posibilidad de reproducirlos en ensayos de corto plazo.

Los productos utilizados para los tratamientos se han elegido entre aquéllos comúnmente usados en Italia, que son aconsejados para la protección de las esculturas policromadas de los "Arconi di San Marco", en Venecia (fotos 1 y 1a) (Fassina y otros, 1987).

\section{EXPERIMENTACIÓN}

Para el estudio se han utilizado dos mármoles de cantera diferentes: Carrara y Proconnesio. Ambos se usan muy a menudo para arquitectura y escultura, no sólo en los monumentos antiguos sino también para los modernos en muchos

\section{INTRODUCTION}

The effectivenness of products used for the conservation of stone is commonly evaluated through the measure of several physical parameters of treated and untreated samples, before and after artificial wathering. This enables us to accelerated the study of the durability of the treatments and thereby reduce experimental time.

Artificial weathering is carried out through cycles, such as freeze-thaw, salt crystallization, acid spraying, etc. These cycles are aimed at the simulation of the effects of outdoor exposure in a given situation.

Nevertheless, natural ageing is a very complex phenomenon in which it is difficult to individualize all the components and their relative importance. So, artificial ageing can hardly simulate a real condition. It only tries to reproduce in a simpler way the effects of the most important factors. Several studies are being carried out in order to improve our knowledge in this field (Zender, Arnold, 1988) (Heiman, 1988) but the problem is still far from a satisfactory solution.

In the present study, an attempt has been made to compare the effects of natural ageing with those of artificial ageing on samples of the same stones untreated or treated with the same waterproofing products, applied with the same methodology.

Experimental results allow a comparison of the total effects of the two weathering methods and a check on the behaviour of the studied treatments under field conditions. Yet we need a deeper comprehension of the mechanisms of alteration and of the possibility to reproduce them by shortterm testing.

The products used for the treatments are choosen among those commonly used in Italy, which were suggested for the protection of polychromed sculptures of the "Arconi di San Marco" in Venice (Phot. 1 and 1a) (Fassina et Al., 1987).

\section{EXPERIMENTAL}

Two different quarry marbles, Carrara and Proconnesion, are used for the study. Both are very frequently utilized for architecture and sculpture, not only in ancient monuments but also for present use in many Countries. 


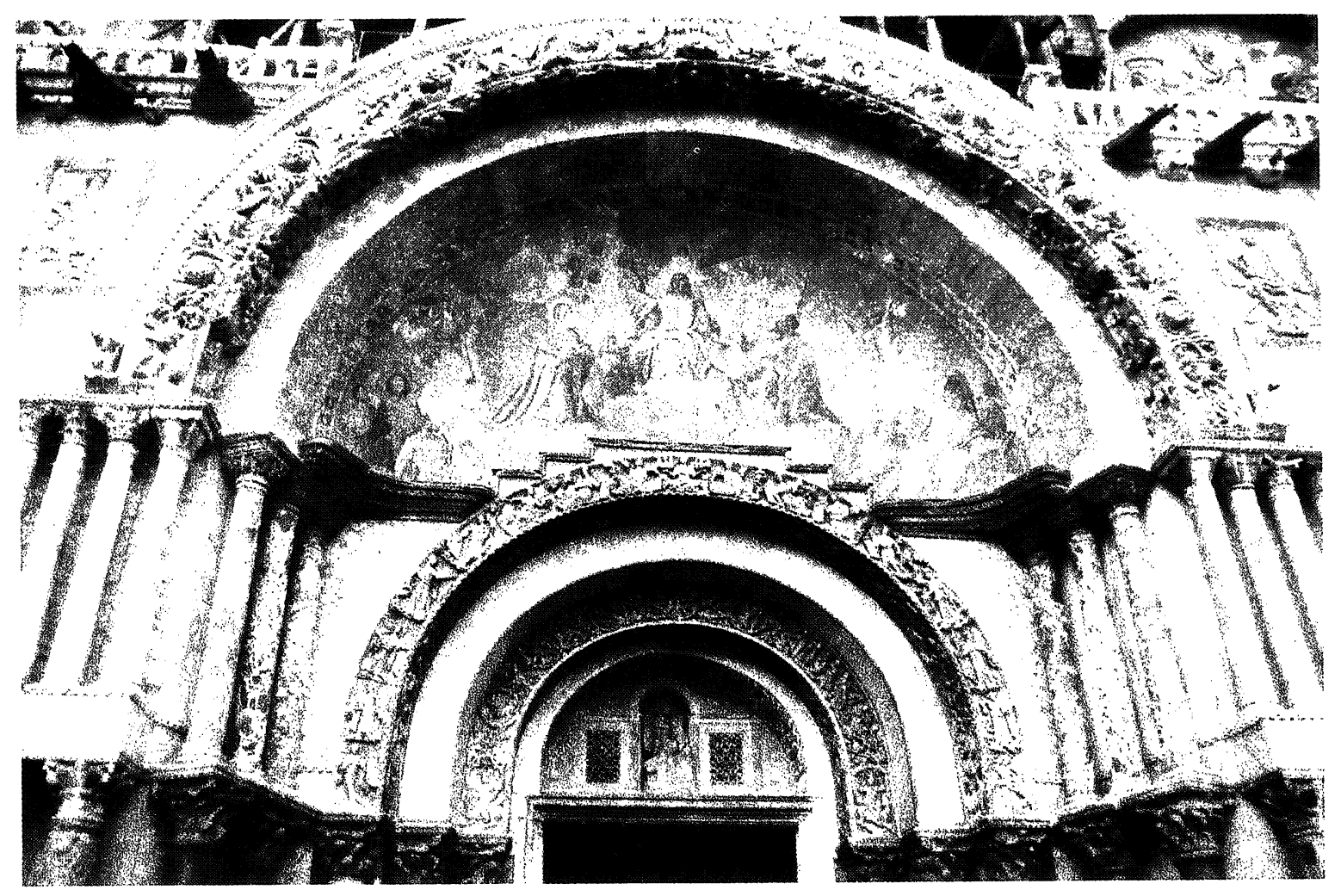

Foto 1.-Los "Arconi" de la Basílica de San Marcos, en Venecia, después de la reciente restauración.

Phot 1.-The "Arconi" of the St. Marcus Basilica, in Venice, after the recent restoration.

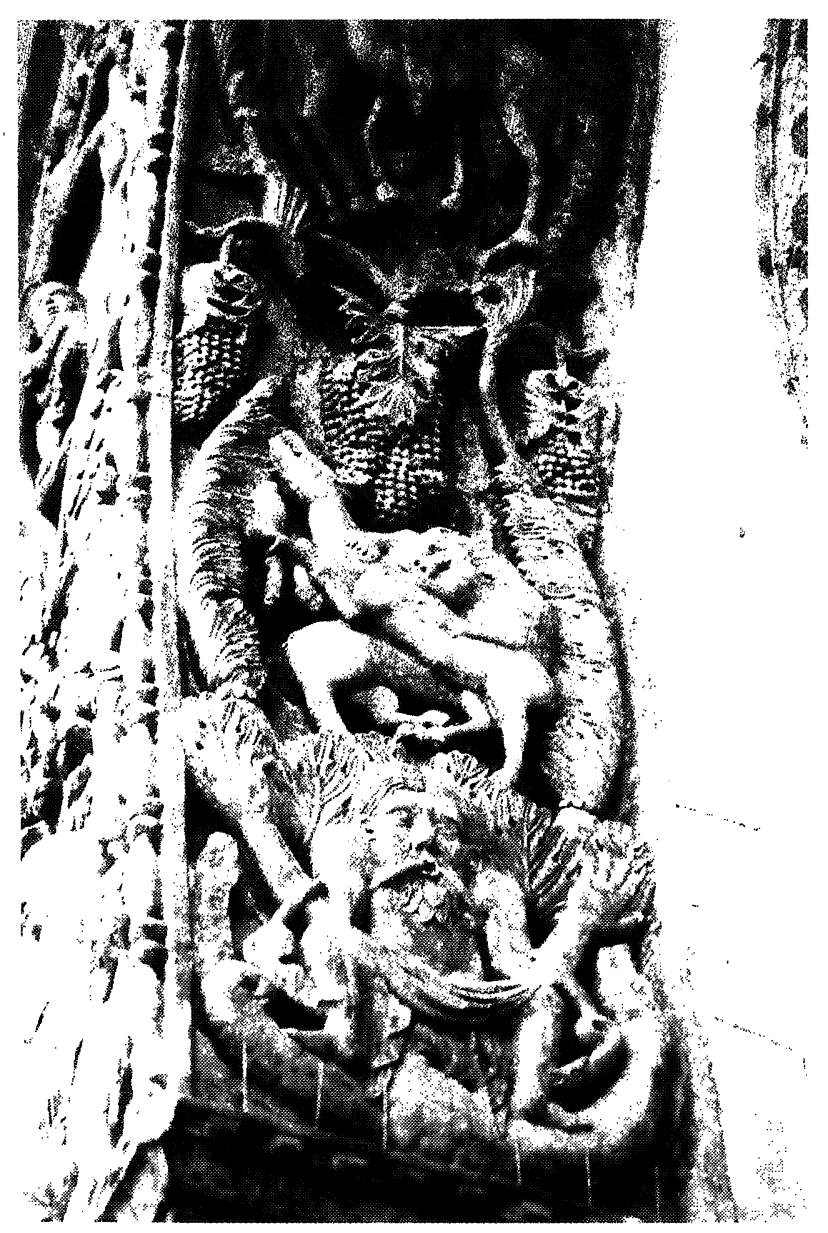

Foto 1a.-Detalle de las esculturas. Phot. 1a.-Detail of the sculptures. 
países. Mientras que el blanco de Carrara puede ser considerado un mármol calcítico puro, el Proconnesio tiene una proporción de Calcita/Dolomita de aproximadamente 4-5 y un contenido de azufre de aproximadamente 0,1\% (Lazzarini, Mariottini, 1987).

Sus estructuras y la medida media de los granos son también bastantes diferentes, $<1 \mathrm{~mm}^{2}$ para el de Carrara y $>1 \mathrm{~mm}^{2}$ para el de Proconnesio (Lazzarini y otros, 1980). La porosidad y la distribución de los tamaños de los poros (medidos con porosímetros a inyección de mercurio Carlo Erba 2000, conforme con el Doc. NORMAL 4/80) se muestran en la Tabla I.
While the white Carrara can be considered a pure calcitic marble, Preconnesion has a

Calcite/Dolomite ratio of about 4-5 and a Sulphur content of around 0.1 \% (Lazzarini, Mariottini, 1987).

Their structure and the average grain size are also rather different, $<1 \mathrm{~mm}^{2}$ for Carrara and $>1 \mathrm{~mm}^{2}$ for Preconnesion (Lazzarini et Al., 1980). The porosity and pore size distribution (measured by a Mercury porosity meter Carlo Erba 2000, according to the Doc. NORMAL 4/80) are shown in Table I.

TABLA I

Porosidad y distribución de los tamaños de los poros

\begin{tabular}{|l|c|c|}
\hline & Carrara & Proconnesio \\
\hline Masa $(\mathrm{g})$ & 9 & 5 \\
Masa vol. aparente $\left(\mathrm{g} / \mathrm{cm}^{3}\right)$ & 2,7 & 2,7 \\
Vol. max. acumulado $\left(\mathrm{cm}^{3} / \mathrm{g}\right)$ & 0,0006 & 0,0008 \\
Porosidad integral abierta $(\%)$ & 0,2 & 0,2 \\
Vol. \% poros con $0,002<\mathrm{d}<0,02 \mu \mathrm{m}$ & 0 & 5 \\
Vol. \% poros con $0,02<\mathrm{d}<0,2 \mu \mathrm{m}$ & 76 & 46 \\
Vol. \% poros con $0,2<\mathrm{d}<2 \mu \mathrm{m}$ & 24 & 49 \\
Vol. \% poros con $2<\mathrm{d} \mu \mathrm{m}$ & 0 & 0 \\
\hline
\end{tabular}

TABLE I

Porosity and Pore size distribution

\begin{tabular}{|l|c|c|}
\hline & Carrara & Proconnesion \\
\hline Mass $(\mathrm{g})$ & 9 & 5 \\
Apparent volumic mass $\left(\mathrm{g} / \mathrm{cm}^{3}\right)$ & 2,7 & 2,7 \\
Cumulative Max. volume $\left(\mathrm{cm}^{3} / \mathrm{g}\right)$ & 0,0006 & 0,0008 \\
Integral open porosity $(\%)$ & 0,2 & 5 \\
Vol. $\%$ of pores with $0,002<\mathrm{d}<0,02 \mu \mathrm{m}$ & 0 & 46 \\
Vol. \% of pores with $0,02<\mathrm{d}<0,2 \mu \mathrm{m}$ & 76 & 49 \\
Vol. $\%$ of pores with $0,2<\mathrm{d}<2 \mu \mathrm{m}$ & 24 & 0 \\
Vol. $\%$ of pores with $2<\mathrm{d} \mu \mathrm{m}$ & 0 & 5 \\
\hline
\end{tabular}


Todas las muestras, de formas y medidas $(5 \times 5 \times 1 \mathrm{~cm})$ regulares han sido previamente alteradas artificialmente con 10 ciclos de cristalización, usando una solución saturada de $\mathrm{Na}_{2} \mathrm{SO}_{4} \cdot(\mathrm{OH})_{2} \mathrm{O}$ (conforme con el Método estándar ASTM C88), para que sus condiciones fueran lo más parecidas posible a aquellas de los mármoles de los monumentos que necesitan ser protegidos.

Los siguientes productos se han aplicado a las muestras:

- SCO. Mezcla de Acril-silicona: "Surface Clear Opaco" por Raccanello. Padova.

- AS. Mezcla de Acril-silicona: "Paraloid B72" por Rohm \& Haas y "Dri Film 104" por General Electric; la mezcla está detallada en la ref. (Nonfarmale. 1975).

— S. Silicona: "Dri Film 104" por General Electric.

— F. Perfluoropolietere: "Fomblin y Met" por Montefluos.

Las resinas SCO, AS y S se han aplicado en capas con una película de espesor de 30 micron. $F$ no forma película dado que queda en un estado líquido y se ha aplicado con una brocha.

Diez muestras de cada tipo de mármol se han tratado con cada uno de los productos ensayados. La preparación de las muestras de mármol y la aplicación de los productos han sido llevadas a cabo por V. Fassina y L. Lazzarini, en el Laboratorio Científico de la Soprintendenza ai Beni Artistici e Storici di Venezia (Fassina y otros, 1987).

Cinco muestras se han sometido a alteración artificial y otras cinco a alteración natural, para cada tipo de mármol y para cada tratamiento.

La alteración artificial se ha llevado a cabo sometiendo las muestras a una solución spray que contenía $\mathrm{NaCl}(5 \mathrm{~g} / 100 \mathrm{ml}$ de agua deionizada) y $\mathrm{H}_{2} \mathrm{SO}_{4}$ con un $\mathrm{pH}$ de $5,0 \pm 0,1 \mathrm{y}$, cíclicamente, a la exposición de lámparas UV a temperatura y humedad relativa fijas.

En total el desgaste duró 33 días: los detalles de la experiencia ya han sido relatados (Fassina y otros, 1987).

Todas las sales solubles en agua producidas durante el desgaste han sido lavadas antes de la medición de los parámetros físicos.

Para el envejecimiento natural un conjunto parecido de muestras se ha expuesto por dos años, desde octubre de 1984 a octubre de 1986,
All the samples, regularly shaped and sized $(5 \times 5 \times 1 \mathrm{~cm})$, have been previously artificially weathered with 10 crystallization cycles, using a saturated solution of $\mathrm{Na}_{2} \mathrm{SO}_{4} \cdot 10 \mathrm{H}_{2} \mathrm{O}$ (according the ASTM C88 Standard Method), in order to make their condition closer to that of monumental marbles that are in need of protection.

The following products have been applied to the marble samples:

- SCO. Acryl-silicone mixture: "Surface Clear Opaco" by Raccanello, Padova.

- AS. Acryl-silicone mixture: "Paraloid B72" by Rohm \& Haas and "Dri Film 104" by General Electric; the mixture is described in ref. (Nonfarmale, 1975).

- S. Silicone resin: "Dri Film 104" by General Electric.

- F. Perfluoropolyether: "Fomblin Y Met "by Montefluos.

The resin SCO, AS and $S$ have been applied by a coater which gives a film of 30 micron thickness. $F$ doesn't form a film as it remains in the liquid state and was applied by brush.

Ten samples of each type of marble have been treated with each of the tested products. The preparation of marble samples and the application of products were carried out by $V$. Fassina and L. Lazzarini at the Scientific Laboratory of the Soprintendenza ai Beni Artistici e Storici di Venezia (Fassina et Al., 1987).

Five samples have been submitted to artificial weathering and the other five to the natural weathering, for each type of marble and for each treatment.

Artificial weathering has been carried out by submitting the samples to a solution spray containing $\mathrm{NaCl}(5 \mathrm{~g} / 100 \mathrm{ml}$ of deionized water) and $\mathrm{H}_{2} \mathrm{SO}_{4}$ at a pH of 5,0 $\pm 0,1$ and, cyclically, to the exposure of a UV lamp at fixed Temperature and Relative Humidity.

As a whole the weathering lasted 33 days; the experimental details have already been described (Fassina et Al., 1987).

All the water soluble salts produced during the weathering were washed out before the measurement of the physical parameters.

For natural ageing an analogous set of samples has been exposed for two years, from October 1984 to October 1986, in the small balcony of the 
en el pequeño balcón de "Casa Borgia" (foto 2), frente a Vía Cavour, una de las calles de más tráfico en el centro de Roma. Las muestras han estado expuestas a la lluvia, con una inclinación de aproximadamente 30 grados; el balcón mira hacia el norte.

Los valores mensuales, promedio mínimo y máximo de la temperatura, y la cantidad total mensual de lluvias en Roma durante el período mencionado, están representados en la Tabla II.

En lo que se refiere a la contaminación del aire en el centro de la ciudad, los datos diponibles indican unos valores medios para el invierno de $>100 \mu \mathrm{g} / \mathrm{m}^{3}$ para el $\mathrm{SO}_{2}, 150 \mu \mathrm{g} / \mathrm{m}^{3}$ para $\mathrm{NO}_{2}$ y $>100 \mu \mathrm{g} / \mathrm{m}^{3}$ para las partículas en suspensión (s.p.m.); mientras que el $\mathrm{SO}_{2}$ muestra una tendencia a disminuir. Las s.p.m., por el contrario, han crecido mucho en la última década (Brocco y otros, 1988 Cosa, Tupini, 1988).

Los parámetros físicos medidos para evaluar los efectos del desgaste son:

- color,

— ángulo de contacto,

- absorción de agua por capilaridad,

- permeabilidad al vapor de agua.
"Case Borgia" (Phot. 2), facing Via Cavour, one of the streets with the heaviest traffic congestion in the centre of Rome. The samples have been kept exposed to rain, with an inclination of about 30 degrees; the balcony is facing north.

The monthly average minimum and maximum values of Temperature, and the monthly total amount of precipitation in Rome during the above period are given in Table II.

As far as air pollution in the town centre is concerned, the available data indicate winter average values $>100 \mu \mathrm{g} / \mathrm{m}^{3}$ for $\mathrm{SO}_{2}, \sim 150 \mu \mathrm{g} / \mathrm{m}^{3}$ for $\mathrm{NO}_{2}$ and $>100 \mu \mathrm{g} / \mathrm{m}^{3}$ for suspended particulate matter (s.p.m.); while $\mathrm{SO}_{2}$ shows a trend to a slight decrease, s.p.m., on the contrary, it has increased sharply in the last decade (Brocco et Al., 1988; Cosa, Tupini, 1988).

The physical parameters measured to evaluate the effect of the weathering are:

- colour,

- contact angle,

- water absorption by capillarity,

- water vapour permeability.

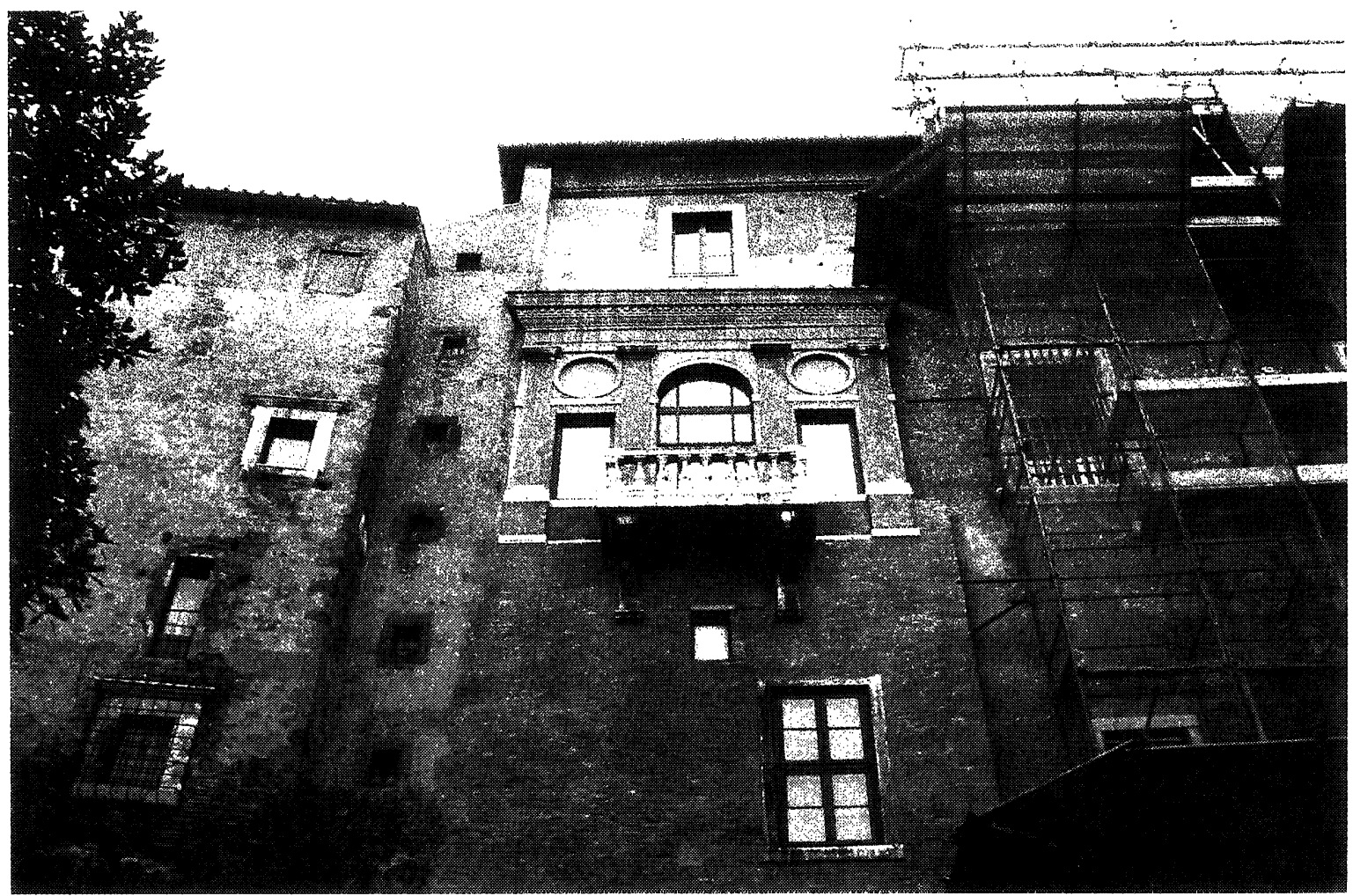

Foto 2.-El balcón de la "Casa Borgia", en el centro de Roma, en donde las muestras fueron expuestas por 2 años.

Phot 2.-The balcony of the "Case Borgia", in the centre of Rome, where the samples were exposed for 2 years. 
TABLA II

Datos metereológicos ( $\left.{ }^{*}\right)$

\begin{tabular}{|c|c|c|c|c|c|c|c|c|c|}
\hline \multirow{2}{*}{ Meses } & \multicolumn{3}{|c|}{1984} & \multicolumn{3}{|c|}{1985} & \multicolumn{3}{|c|}{1986} \\
\hline & $\underset{\mathbf{C}^{\circ}}{\overline{\mathrm{T}} \max }$ & $\underset{\mathbf{C}^{\circ}}{\bar{T} \min }$ & $\begin{array}{c}\text { Precip. } \\
\mathbf{m m}\end{array}$ & $\begin{array}{c}\bar{T} \max \\
\mathbf{C}^{\circ}\end{array}$ & $\underset{\mathbf{C}^{\circ}}{\bar{T} \min }$ & $\begin{array}{c}\text { Precip. } \\
\text { mm }\end{array}$ & $\underset{\mathbf{C}^{\circ}}{\overline{\mathrm{T}} \max }$ & $\underset{\mathbf{C}^{\circ}}{\bar{T} \min }$ & $\begin{array}{c}\text { Precip. } \\
\text { mm }\end{array}$ \\
\hline Ene. & & & & 8,6 & 2,3 & 125,9 & 11,4 & 4,8 & 180,8 \\
\hline Feb & & & & 12,7 & 5,5 & 9,2 & 10,4 & 4,2 & 155,8 \\
\hline Mar. & & & & 14,1 & 6,9 & 92,0 & 15,1 & 7,7 & 48,4 \\
\hline Abr. & & & & 18,9 & 10,8 & 10,8 & 18,3 & 10,0 & 103,6 \\
\hline May. & & & & 24,0 & 14,5 & 39,4 & 25,7 & 15,9 & 0,4 \\
\hline Jun. & & & & 28,6 & 18,1 & 2,6 & 26,3 & 16,8 & 26,8 \\
\hline Jul. & & & & 32,4 & 21,6 & 0,0 & 29,2 & 19,6 & 102,2 \\
\hline Ago. & & & & 30,0 & 20,6 & 10,6 & 31,1 & 21,0 & 0,0 \\
\hline Set. & & & & 28,2 & 18,4 & 11,0 & 26,1 & 16,8 & 75,0 \\
\hline Oct. & 21,1 & 13,6 & 104,2 & 22,0 & 13,2 & 86,6 & 22,6 & 13,7 & 40,6 \\
\hline Nov. & 16,9 & 9,7 & 147,4 & 15,1 & 9,4 & 194,4 & & & \\
\hline Dic. & 13,0 & 6,0 & 54,0 & 13,8 & 6,6 & 34,6 & & & \\
\hline
\end{tabular}

(*) Los datos son recogidos por el Ministero dell'Agricoltura e Foreste, Ufficio Centrale di Ecologia Agraria, Osservatorio del Collegio Romano, Torre Calandrelli, Roma.

TABLE II

Meteorological Data $\left(^{\star}\right)$

\begin{tabular}{|c|c|c|c|c|c|c|c|c|c|}
\hline \multirow{2}{*}{ Meses } & \multicolumn{3}{|c|}{1984} & \multicolumn{3}{|c|}{1985} & \multicolumn{3}{|c|}{1986} \\
\hline & $\underset{\mathbf{C}^{\circ}}{\overline{\mathrm{T}} \max }$ & $\underset{\mathbf{C}^{\circ}}{\bar{T} \min }$ & $\begin{array}{c}\text { Precip. } \\
\text { mm }\end{array}$ & $\underset{\mathbf{C}^{\circ}}{\overline{\mathbf{T}} \max }$ & $\underset{\mathbf{C}^{\circ}}{\bar{T} \min }$ & $\begin{array}{c}\text { Precip. } \\
\text { mm }\end{array}$ & $\underset{\mathbf{C}^{\circ}}{\overline{\mathbf{T}} \max }$ & $\underset{\mathbf{C}^{\circ}}{\bar{T} \min }$ & $\begin{array}{c}\text { Precip. } \\
\text { mm }\end{array}$ \\
\hline Jan & & & & 8,6 & 2,3 & 125,9 & 11,4 & 4,8 & 180,8 \\
\hline Feb & & & & 12,7 & 5,5 & 9,2 & 10,4 & 4,2 & 155,8 \\
\hline Mar & & & & 14,1 & 6,9 & 92,0 & 15,1 & 7,7 & 48,4 \\
\hline Apr & & & & 18,9 & 10,8 & 10,8 & 18,3 & 10,0 & 103,6 \\
\hline May & & & & 24,0 & 14,5 & 39,4 & 25,7 & 15,9 & 0,4 \\
\hline Jun & & & & 28,6 & 18,1 & 2,6 & 26,3 & 16,8 & 26,8 \\
\hline Jul & & & & 32,4 & 21,6 & 0,0 & 29,2 & 19,6 & 102,2 \\
\hline Aug & & & & 30,0 & 20,6 & 10,6 & 31,1 & 21,0 & 0,0 \\
\hline Sep & & & & 28,2 & 18,4 & 11,0 & 26,1 & 16,8 & 75,0 \\
\hline Oct & 21,1 & 13,6 & 104,2 & 22,0 & 13,2 & 86,6 & 22,6 & 13,7 & 40,6 \\
\hline Nov & 16,9 & 9,7 & 147,4 & 15,1 & 9,4 & 194,4 & & & \\
\hline Dec & 13,0 & 6,0 & 54,0 & 13,8 & 6,6 & 34,6 & & & \\
\hline
\end{tabular}

(") Data collected by Ministero dell'Agricoltura e Foreste, Ufficio Centrale di Ecologia Agraria, Osservatorio del Collegio Romano, Torre Calandrelli, Roma. 
En el caso de muestras desgastadas naturalmente se ha llevado a cabo una evaluación cuantitativa del polvo depositado en sus superficies.

Salvo para el color, todas las mediciones se han realizado sobre las muestras lavadas y secadas.

\section{RESULTADOS Y DISCUSIÓN}

En los epígrafes siguientes se exponen los resultados de la experiencia, haciendo comparaciones entre las muestras antes del desgaste y aquellas que se han envejecido artificial y naturalmente. Las primeras dos series de resultados ya han sido publicadas en un trabajo anterior (Fassina y otros, 1987).

A menos que se especifique claramente, los resultados se dan como valores medios de cinco muestras por cada tratamiento.

\subsection{Color}

El color se ha medido por comparación con la Munsell Colour Charts (ASTM, 1968); los resultados se dan en la Tabla III, expresados como valores promedio aritméticos, aunque no siempre correspondan a los escalones de la Munsell Neutral Scale.

Como se puede ver en las fotos 3 y 4 , las muestras expuestas en el exterior aparecen bastante sucias debido a los depósitos de polvo. Este hecho ha tenido una clara influencia en el color de la superficie.

La alteración artificial no cambia el color del mármol de Carrara no tratado o tratado con AS y $S$. En el caso del Fomblin se ha comprobado sólo un muy pequeño oscurecimiento, mientras que las muestras tratadas con SCO se han vuelto amarillas después de la primera etapa de alteración superficial; al término del envejecimiento el color amarillo desaparece, debido a la desaparición de la resina de la superficie.

Después del envejecimiento natural, el Carrara no tratado y las muestras tratadas con $S$ se han oscurecido ligeramente: ambos valores de Neutro ( $N$ \%) y Reflexión (R \%) se han reducido. En comparación con los valores medidos antes del desgaste, la exposición en el exterior produce una mejora con el tratamiento $F$, bien respecto de los valores iniciales y bien de los valores posteriores al desgaste artificial ( $N$ y $R \%$ se han vuelto más parecidos a los valores de las muestras no tratadas).

SCO y AS muestran el más fuerte oscurecimiento, debido a un considerable depósito de polvo, y se han vuelto un poco
In the case of the samples naturally weathered a quantitative evaluation of the dust deposited on their surface has been carried out.

Except for colour, all the measures have been carried out on washed and dried samples.

\section{RESULTS AND DISCUSSION}

In the following paragraphs the experimental results are given, making a comparison among the samples before the weathering and those which are artificially and naturally aged. The first two seried of results were already published in a previous paper (Fassina et Al., 1987).

Unless differently stated, the results are given as average values of five samples for each treatment.

\subsection{Colour}

The colour has been measured by comparison with the Munsell Colour Charts (ASTM, 1968); the results are given in Table III, expressed as arithmetic average values even if they don't always correspond to the steps of the Munsell Neutral Scale.

As shown in photographs 3 and 4, the samples exposed outdoor appear rather soiled due to the deposition of dust. This has had a clear influence on the surface colour.

Artificial weathering doesn't change the colour of Carrara marble untreated or treated with AS and $S$. In the case of Fomblin only a very slight darkening is measured, while the samples treated with SCO turned yellow after the first step of weathering. At the end of the experiment the yellowing disappears, due to the disappearance of the resin from the surface.

After natural ageing the untreated Carrara and the samples treated with $S$ are slightly darker: both Neutral value $(N)$ and Reflectance \% (R\%) decrease. In comparison with the values measured before the weathering, the outdoor exposure produces an improvement on treatment $F$, both in respect to the initial values and to the values after artificial weathering ( $N$ and $R \%$ become more similar to the values of the untreated samples).

SCO and AS show the strongest darkening, corresponding to a heavy deposition of dust, and some yellowing. Therefore, the colour 
TABLA III

Mediciones del color

\begin{tabular}{|c|c|c|c|}
\hline Tratamiento & Antes desgaste & Después desgaste artif. & Después desgaste nat. \\
\hline \multicolumn{4}{|c|}{ Mármol de Carrara } \\
\hline Sin tratar & $9,25 N-84 R \%$ & $9,25 N-84 R \%$ & $9,10 N-81 R \%$ \\
\hline sco & $9,25 N-84 R \%$ & $9,25 N-84 R \%$ & $5 Y, 8 / 1$ \\
\hline AS & $9,25 N-84 R \%$ & $9,25 N-84 R \%$ & $5 Y, 7 / 2$ \\
\hline S & $9,20 N-83 R \%$ & $9,20 N-83 R \%$ & $9,10 N-81 R \%$ \\
\hline $\mathrm{F}$ & $8,87 N-75 R \%$ & $8,85 N-75 R \%$ & $9,10 \mathrm{~N}-80 \mathrm{R} \%$ \\
\hline \multicolumn{4}{|c|}{ Mármol Proconnesio } \\
\hline Sin tratar & & & $8 N-59 R \%$ \\
\hline sco & & & $2,5 Y, 7 / 1-6 / 1$ \\
\hline AS & & & $\{2,5 Y, 6 / 2$ \\
\hline & & & $\{10 Y R, 6 / 1$ \\
\hline s & & & $7,8 \mathrm{~N}-55 \mathrm{R} \%$ \\
\hline $\mathrm{F}$ & & & $7,9 N-57,4 R \%$ \\
\hline
\end{tabular}

$\mathrm{N}=$ Valor neutral; $\mathrm{R}=$ Reflexión $\%$.

TABLE III

Colour Measurements

\begin{tabular}{|c|c|c|c|}
\hline Treatment & Before weathering & After Artif. Weath. & After Nat. Weath. \\
\hline \multicolumn{4}{|c|}{ Carrara Marble } \\
\hline Untreated & $9,25 N-84 R \%$ & $9,25 N-84 R \%$ & $9,10 N-81 R \%$ \\
\hline sco & $9,25 N-84 R \%$ & $9,25 N-84 R \%$ & $5 Y, 8 / 1$ \\
\hline AS & $9,25 N-84 R \%$ & $9,25 N-84 R \%$ & $5 Y, 7 / 2$ \\
\hline s & $9,20 N-83 R \%$ & $9,20 N-83 R \%$ & $9,10 N-81 R \%$ \\
\hline $\mathrm{F}$ & $8,87 N-75 R \%$ & $8,85 N-75 R \%$ & $9,10 N-80 R \%$ \\
\hline \multicolumn{4}{|c|}{ Proconnesion Marble } \\
\hline Untreated & & & $8 N-59 R \%$ \\
\hline sco & & & $2,5 Y, 7 / 1-6 / 1$ \\
\hline AS & & & $\{2,5 Y, 6 / 2$ \\
\hline & & & $\{10 Y R, 6 / 1$ \\
\hline s & & & $7,8 \mathrm{~N}-55 \mathrm{R} \%$ \\
\hline $\mathrm{F}$ & & & $7,9 N-57,4 R \%$ \\
\hline
\end{tabular}

$N=$ Neutral value; $R=$ Reflectance $\%$ 


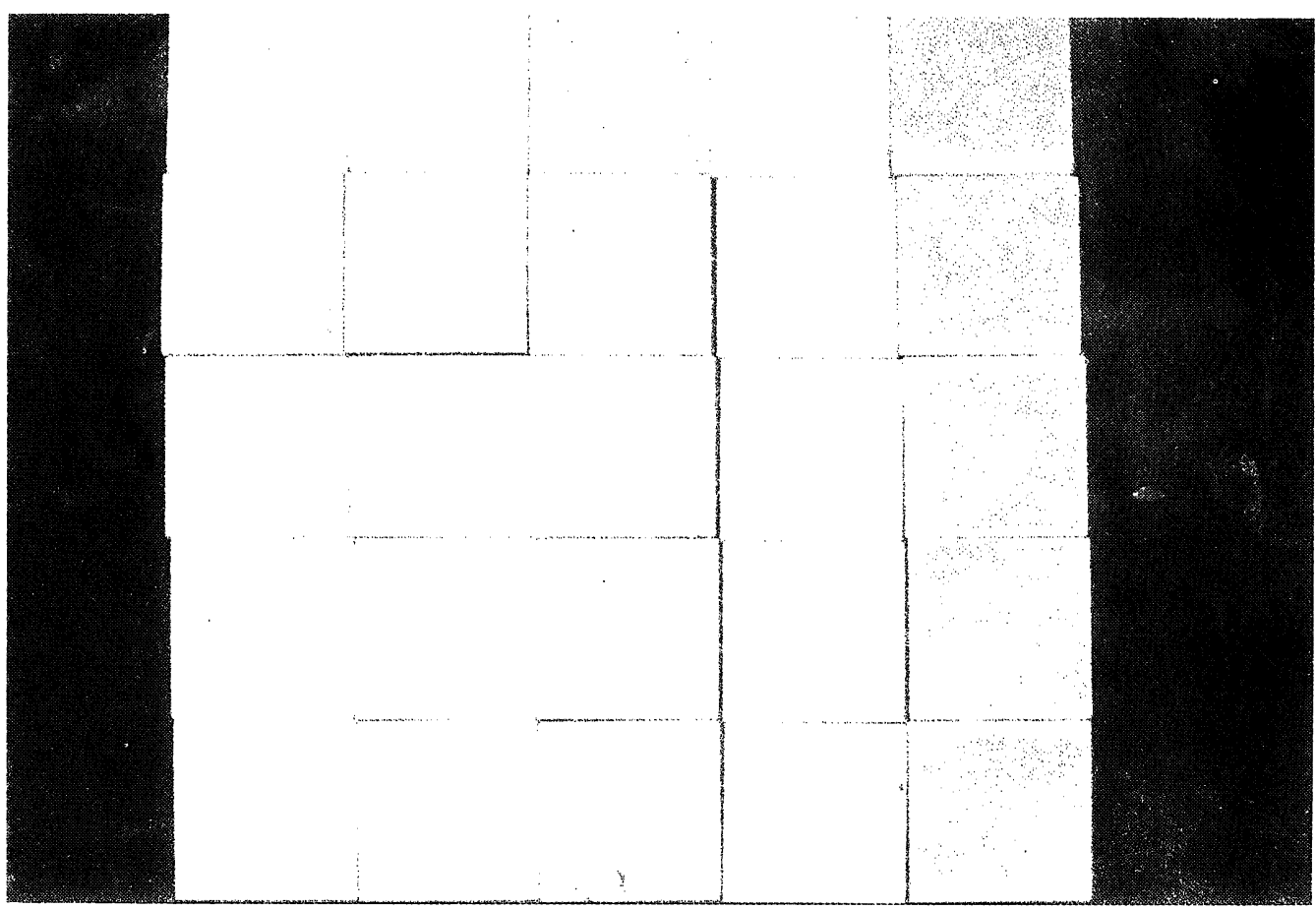

Foto 3.-Muestra de Carrara después de 2 años de exposición en el exterior. Desde la izquierda: F (Fomblin). Sin tratar, SCO (Surface Clear Opaco), S (Dri film 104), AS (Paraloid B72 + Dri Film 104).

Phot 3.-Carrara samples after 2 year of autdoor exposure. From the left: F (Fomblin), Untreated, SCO (Surface Clear Opaco), $S$ (Dri Film 104); AS (Paraloid B72 * Dri Film 104).

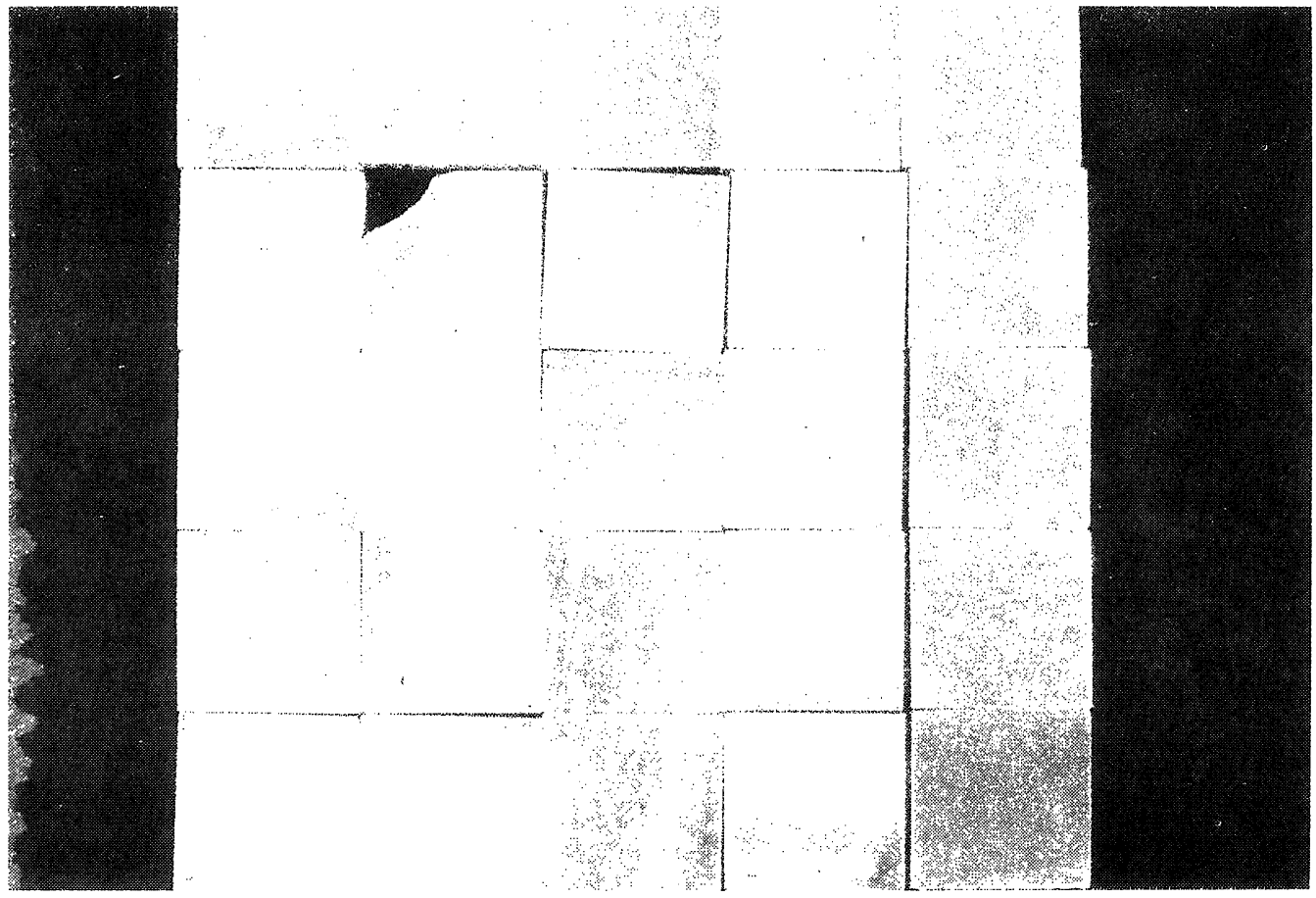

Foto 4.-Muestras de Proconnesio después de 2 años de exposición en el exterior. Desde la izquierda: $F$ (Fomblin). Sin tratar, SCO (Surface Clear Opaco), S (Dri Film 104), AS (Paraloid B72 + Dri Film 104).

Phot 4.-Proconnesion samples after 2 year of autdoor exposure. From the left: F (Fomblin), Untreated, SCO (Surface Clear Opaco), $S$ (Dri Film 104), AS (Paraloid B72 + Dri Film 104). 
amarillas. Sin embargo, las mediciones de los colores han sido posibles sólo en comparación con la Tabla Munsell Y (Yellow). En lo que se refiere al Proconnesio, la evaluación de los cambios de colores es más difícil debido a la variedad de los tonos de gris del mármol. Es sin embargo posible comprobar que el envejecimiento artificial no da una variación importante para todos los tratamientos, salvo para el SCO, el cual muestra el mismo comportamiento antes detallado para el mármol de Carrara.

Las muestras de Proconnesio aparecen un poco más sucias que las muestras de Carrara. En particular, SCO y AS muestran el mismo oscurecimiento fuerte y color amarillo, ya detallados para el mármol de Carrara, mientras que otros tratamientos dan sólo pequeñas variaciones que son difíciles de evaluar, debido a la variabilidad de color de este mármol.

Posteriormente a las mediciones del color, todas las muestras se han sumergido en una cantidad establecida de agua desionizada durante 96 horas sobre un agitador oscilante para lavarlos y extraer las sales solubles en agua que se hayan producido.

La conductividad específica de las soluciones se ha medido y los residuos insolubles se han recogido por medio de filtrado con filtros calibrados. Los resultados se recogen en la Tabla IV.

No se ha encontrado correlación entre las variaciones de color y los pesos del residuo soluble, probablemente porque el color negro es principalmente debido a los productos carbonosos con densidad baja, que afecta muy poco el peso del residuo insoluble, $y$, es más, porque la suciedad se puede formar no sólo por el polvo atmosférico, sino también con el polvo proveniente de las muestras y de los productos aplicados (foto 5). Las hipótesis mencionadas, sin embargo, se deberían de confirmar con análisis químicos del residuo insoluble.

La cantidad total de las partículas insolubles recogidas de las muestras de Carrara es levemente más alta de la cantidad del Proconnesio, cosa que está de acuerdo con la aparencia más sucia de las primeras. Además, los valores de la conductividad específica de los productos estraidos del agua del mármol de Carrara son un poco más altos que los correspondientes valores del de Proconnesio.

El peso del "polvo" y la conductividad específica del extracto de agua ofrecen sólo una primera indicación del grado de deterioro de los dos mármoles después del desgaste natural. Los cambios de color son, por el contrario, de la máxima importancia en la evaluación de los productos utilizados para la protección de las obras de arte. measurements have been possible only by the comparison with the $Y$ (yellow) Table. As far as the Proconnesion is concerned, the evaluation of colour changes is much more difficult due to the variability of the gray tone of the marble. It is, however, possible to ascertain that the artificial ageing doesn't give any significant variation for all the treatments, except for SCO which shows the same behaviour as that previously described for Carrara marble.

The Proconnesion samples appear lightly less soiled than the Carrara samples. In detail, SCO and $A S$ show the same strong darkening and yellowing already described for Carrara marble, while the other treatments give only slight variations which are difficult to evaluate because of the variability of colour in this marble. This is due to the presence of grey veins in the marble.

After the colour measurements all samples have been immersed in a fixed amount of deionized water for 96 hours on a shaking table in order to wash them and to extract the water soluble salts possibly produced by pollution.

The specific conductivity of the solutions has been measured and the insoluble residue has been collected by filtration on calibrated filters. The results are given in Table IV.

No correlation has been found between the colour variations and the weights of the insoluble residue probably because the black colour is mainly due to carbonaceous products with low bulk density, scarcely influencing the weight of the insoluble residue, and, moreover, because the latter can be formed not only by the atmospheric dust but also by powder coming from the sample and from the applied product (phot. 5). The above hypothesis, however, should be confirmed by the chemical analysis of the insoluble residue.

The total amount of insoluble matter collected from the Carrara samples is slightly higher than the amount from Proconnesion, which is in accordance with the dirtier appearance of the first ones. Moreover, the values of the specific conductivity of the Carrara water extracts are a little bit higher than the corresponding values for Proconnesion.

The weight of the "dust" and the specific conductivity of the water extract give only a first, rough indication of the degree of deterioration of the two marbles after natural weathering. The colour changes are, on the contrary, of the utmost importance in the evaluation of products to be used for the protection of works of art. 
TABLA IV

Residuo insoluble y conductividad espec. de los extractos acuosos ( ${ }^{*}$ )

\begin{tabular}{|l|c|c|c|c|}
\hline \multirow{2}{*}{ Tratamiento } & \multicolumn{2}{|c|}{ Mármol Carrara } & \multicolumn{2}{c|}{ Mármol Proconnesio } \\
\cline { 2 - 5 } & Ins. Res. $\mathbf{m g}$ & Spec. Cond. $\mu \mathrm{S} / \mathrm{cm}$ & Ins. Res. $\mathrm{mg}$ & Spec. Cond. $\mu$ S/cm \\
\hline Sin tratar & 10 & $93 \pm 17$ & 2 & $82 \pm 6$ \\
SCO & 4 & $87 \pm 9$ & 4 & $86 \pm 8$ \\
AS & 12 & $118 \pm 14$ & 4 & $83 \pm 2$ \\
S & 2 & $94 \pm 2$ & 2 & $82 \pm 3$ \\
F & 4 & $100 \pm 13$ & 4 & $101 \pm 8$ \\
\hline
\end{tabular}

(") Error dado como máximo de la semi-dispersión (max-min)/2.

TABLE IV

Insoluble residue and Spec. Conductivity of Water Extracts (*)

\begin{tabular}{|l|c|c|c|c|}
\hline \multirow{2}{*}{ Treatment } & \multicolumn{2}{|c|}{ Carrara Marble } & \multicolumn{2}{c|}{ Proconnesion Marble } \\
\cline { 2 - 5 } & Ins. Res. $\mathbf{m g}$ & Spec. Cond. $\mu$ S/cm & Ins. Res. $\mathrm{mg}$ & Spec. Cond. $\boldsymbol{\mu S} / \mathrm{cm}$ \\
\hline Untreated & 10 & $93 \pm 17$ & 2 & $82 \pm 6$ \\
SCO & 4 & $87 \pm 9$ & 4 & $86 \pm 8$ \\
AS & 12 & $118 \pm 14$ & 4 & $83 \pm 2$ \\
S & 2 & $94 \pm 2$ & 2 & $82 \pm 3$ \\
F & 4 & $100 \pm 13$ & 4 & $101 \pm 8$ \\
\hline
\end{tabular}

(*) Error given as maximum of the semi-dispersion $(\max -\min ) / 2$.

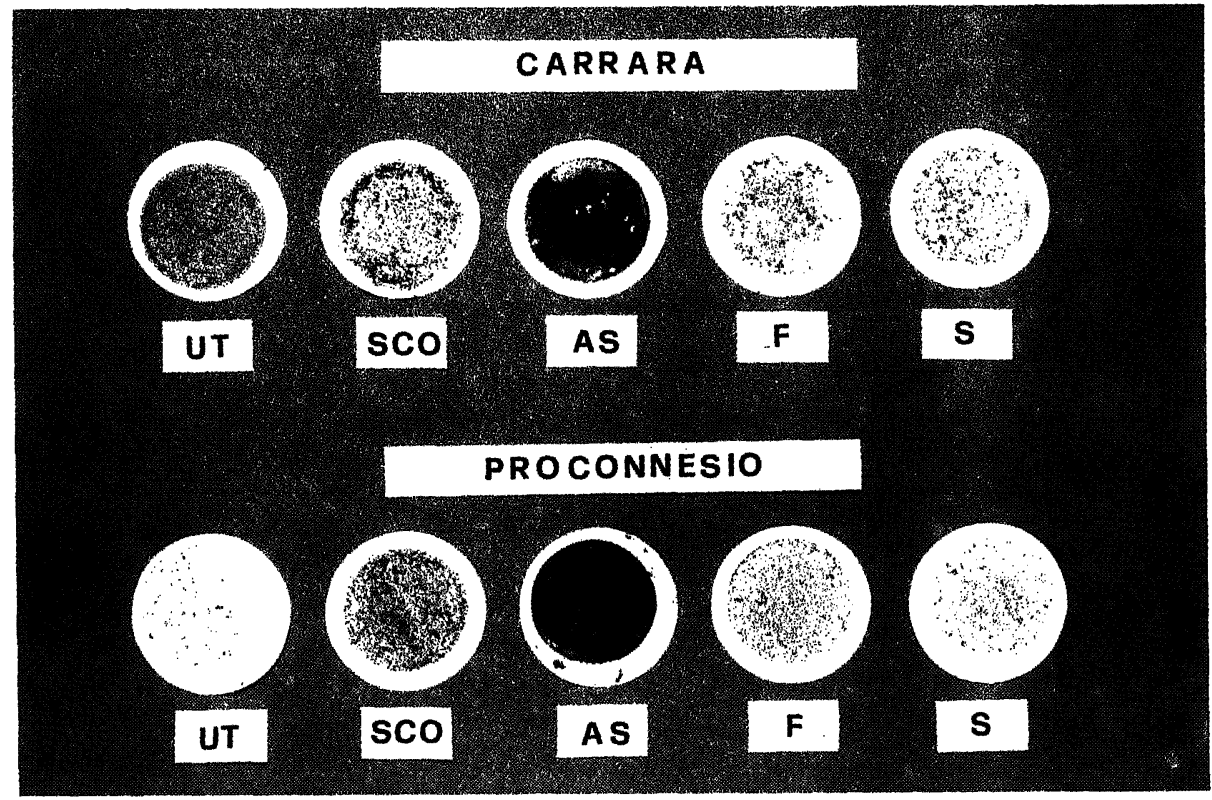

Foto 5.-Filtros de papel para recoger el polvo depositado sobre las diferentes muestras.

Phot 5.-Paper filters collecting the dust deposited on the different samples. 


\section{2. Ángulo de contacto}

Un instrumento Lorentz \& Wettre (Suecia) ha sido utilizado y permite la lectura directa de la altura y diámetro de las gotas. Las lecturas se han llevado a cabo 15 segundos después de la deposición de la gota sobre la superficie de la muestra. Se han tomado treinta mediciones para cada conjunto de muestras: los valores promedio y sus desviaciones estandar se representan en la Tabla V.

Desde un punto de vista general, los efectos producidos sobre el ángulo de contacto por las dos condiciones de desgaste pueden ser considerados bastante parecidos; sin embargo, los resultados de este ensayo son de difícil interpretación, probablemente debido a su alta dispersión.

Para el mármol de Carrara el ángulo de contacto de los tratamientos $S$ y $F$ muestra siempre una rápida disminución, mientras que para el SCO la disminución no es tan marcada. Muy extrañamente, el tratamiento AS mejora después del desgaste artificial y queda prácticamente invariable después de la exposición en el exterior. En el caso de las muestras sin tratar, debido a una cierta heterogeneidad de las superficies naturales, los valores del ángulo de contacto, antes y después de los dos tipos de ensayos, se pueden considerar prácticamente constantes.

En el caso del Proconnesio, los efectos de la alteración natural, con relación al ángulo de contacto, están conformes con aquéllos logrados con la alteración artificial, salvo para el tratamiento SCO que queda prácticamente invariable en el primer caso, mientras que se ve muy fuertemente afectado por el desgaste en el laboratorio.

\subsection{Absorción del agua por capilaridad}

Las mediciones se han llevado a cabo siguiendo la metodología Normal (NORMAL 11/85) y los resultados se dan en la Tabla $\mathrm{VI}$, en donde el Coeficiente de Capilaridad C.A. $\left(\mathrm{g} / \mathrm{cm}^{2} \cdot \mathrm{s}^{1 / 2}\right)$ y los valores asintóticos de la absorción del agua por unidad de superficie $M\left(\mathrm{~g} / \mathrm{cm}^{2}\right)$ se dan antes $y$ después de la alteración.

Estos valores se han deducido de los gráficos experimentales en los que se relacionan los valores medios del agua absorbida por unidad de superficie versus la raíz cuadrada del tiempo. Como consecuencia, el error no está indicado.

La tendencia de la absorción por capilaridad en los dos tipos de mármol, tanto después de la alteración natural como de la artificial, es bastante parecida. El aumento de los valores de $M$ es mayor para las dos piedras después del

\subsection{Contact angle}

A Lorentz \& Wettre Instrument (Sweden) was used which allows a direct reading of the height and diameter of the drops, without taking photos. The readings were always carried out 15 seconds afther the deposition of the drop on the sample surface. Thirty measures were taken for each set of samples; the average values and their standard deviation are given in Table $\mathrm{V}$.

From a general point of view, the effects produced by the two weathering conditions can be considered rather similar, however, the results of this test are difficult to interpretate, probably because of their high dispersion.

For Carrara marble the contact angle of treatments $S$ and $F$ shows always a sharp decrease, while for SCO the decrease is not so accentuated. Strangely enough, the treatment AS improves afther the artificial weathering and remains practically unchanged afther outdoor exposure. In the case of the untreated samples, due to a certain heterogenity of natural surfaces, the values of contact angle, before and afther the two types of weathering, can be considered practically constant.

In the case of Proconnesion, the effects of natural weathering on contact angle are in good agreement with those obtained with the artificial one, except for treatment SCO which remains practically unchanged in the first case, whereas it is strongly affected by the laboratory weathering.

\subsection{Water absorption by capillarity}

The measures have been carried out following the Normal methodology (NORMAL 11/85) and the results are given in Table VI, where the Capillarity Coefficient C.A. $\left(\mathrm{g} / \mathrm{cm}^{2} \cdot \mathrm{s}^{1 / 2}\right)$ and the asymptotic values of water absorption per unit surface $M$ $\left(\mathrm{g} / \mathrm{cm}^{2}\right)$ are given, before and after weathering.

These values have been obtained from experimental graphs of the average values of water absorbed per unit surface versus the square root of time. As a consequence, error is not indicated.

The trend of capillarity absorption of the two types of marble, after both natural and artificial weathering is rather similar. The increase of the values of $M$ is higher for the two stones after natural ageing. The increase of the C.A. values is 
envejecimiento natural. El aumento de los valores de C.A. es mayor sólo en el caso de las muestras de Proconnesio expuestas en el exterior.

El aumento más marcado de C.A. y $M$ se ha registrado con el tratamiento $\mathrm{F}$ aplicado a las muestras de Carrara.

\subsection{Permeabilidad al vapor de agua}

Se ha seguido la metodología Normal (NORMAL 21/85), utilizando una "taza húmeda" expuesta a la atmósfera seca con muestras de $1 \mathrm{~cm}$ de espesor, con la superficie tratada hacia arriba. Los resultados dados en la Tabla VII son los valores medios de cada conjunto de muestras, expresados en gramos de agua evaporada a través de la superficie unitaria $\left(\mathrm{m}^{2}\right)$ en 24 horas, a $20 \pm 1^{\circ} \mathrm{C}$. El error es calculado como el máximo de la semi-dispersión $=($ máx-mín $) / 2$, porque las medidas fueron llevadas a cabo sólo sobre cinco muestras para cada tipo de tratamiento.

Los dos tipos de envejecimiento producen un aumento en los valores de las muestras tratadas, mientras que aquéllas no tratadas quedan constantes o hasta disminuyen un poco, como en el caso del mármol de Carrara. La influencia de la exposición natural produce una variación más fuerte en comparación con la exposición artificial sobre las muestras de Proconnesio, en tanto que el efecto sobre el mármol de Carrara no es tan unívoco. Para los tratamientos AS y $\mathrm{F}$ el desgaste natural no ha sido tan agresivo como el desgaste artificial, pero la situación es al revés en el caso del tratamiento AS.

\section{CONCLUSIONES}

Los resutados anteriores permiten considerar algunas de las conductas de los tratamientos estudiados cuando se exponen a condiciones reales. Los resultados también ofrecen una comparación de los efectos producidos por la alteración natural y la artificial.

Después de dos años de exposición en el exterior y después del envejecimiento artificial la acción protectora de todos los tratamientos ensayados disminuye y en algunos casos hasta desaparece.

Cuando se comparan los resultados de cada uno de los parámetros medidos, después de los dos tipos de alteración (natural y artificial), el orden de calidad de los cuatro tratamientos queda el mismo para el mejor y para el peor, mientras que alguna variación se ha observado para los otros, como se muestra en la Tabla VIII. Una excepción se observa con los resultados de la permeabilidad de las muestras de Carrara tratadas con AS, y por aquéllos del ángulo de contacto para las muestras de Proconnesio tratadas con SCO y S. higher only in the case of Proconnesion samples exposed outdoors.

The sharpest increase of C.A. and $M$ has been registered with the treatment $F$ applied on Carrara samples.

\subsection{Water vapour permeability}

The Normal methodology has been followed (NORMAL 21/85), using a "wet cup" exposed to the dry atmosphere on $1 \mathrm{~cm}$ thick samples with the treated surface facing upwards. The results given in Table VII are the average values of each set of samples, expressed as grammes of water evaporated through the unit surface $\left(\mathrm{m}^{2}\right)$ in 24 hours, at $20 \pm 1^{\circ} \mathrm{C}$. The error is calculated as the maximum of the semi-dispersion $=($ maxmin)/2 because the measurements were carried out only on five samples for each type of treatment.

Both the two types of ageing produce an increase in the values of the treated samples, while the untreated ones remain constant or even slightly decrease, as in the case of Carrara marble. The influence of the natural exposure produces a stronger variation compared to the artificial exposure on Proconnesion samples, while the effect on Carrara marble is not so univocal. For the treatments $A S$ and $F$ natural weathering has been not so aggressive as the artificial weathering, but the situation is reversed in the case of the AS treatment.

\section{CONCLUSIONS}

The above results allow us to consider some of the behaviour of the studied treatments when exposed to real conditions. The results also offer us a comparison of the effects produced by artificial and natural weathering.

After two years in outdoor exposure and after artificial ageing the protective action of all the tested treatments decreases and in some cases even disappears.

When comparing the results of each of the measured parameters, after the two weatherings, the ranking order of the four treatments remains the same for the best and the worst one, while some variation is observed for the other ones, as shown in Table VIII. An exception is given by the results for water vapour permeability for the Carrara samples treated with AS and by those of contact angle for the Proconnesian samples treated with SCO and S. 
TABLA V

Ángulo de contacto $\alpha$ (grados) ( $\left.{ }^{*}\right)$

\begin{tabular}{|c|c|c|c|}
\hline Tratamiento & Antes desgaste & Después desgaste artif. & Después desgaste nat. \\
\hline \multicolumn{4}{|c|}{ Mármol de Carrara } \\
\hline Sin tratar & $70 \pm 10$ & $71 \pm 7$ & $63 \pm 9$ \\
\hline $\mathrm{sco}$ & $84 \pm 6$ & $69 \pm 6$ & $72 \pm 6$ \\
\hline AS & $79 \pm 5$ & $90 \pm 7$ & $77 \pm 9$ \\
\hline$S$ & $93 \pm 8$ & $61 \pm 5$ & $51 \pm 7$ \\
\hline$F$ & $80 \pm 7$ & $59 \pm 10$ & $51 \pm 10$ \\
\hline \multicolumn{4}{|c|}{ Mármol Proconnesio } \\
\hline Sin tratar & $62 \pm 12$ & $61 \pm 10$ & $62 \pm 6$ \\
\hline $\mathrm{ScO}$ & $78 \pm 9$ & $52 \pm 7$ & $83 \pm 7$ \\
\hline AS & $78 \pm 5$ & $91 \pm 7$ & $85 \pm 9$ \\
\hline $\mathrm{s}$ & $90 \pm 7$ & $75 \pm 13$ & $58 \pm 6$ \\
\hline$F$ & $77 \pm 6$ & $66 \pm 10$ & $72 \pm 6$ \\
\hline
\end{tabular}

$\alpha=2$ arctang (2h/d) en donde $\mathrm{h}$ es la altura de la gotita y $\mathrm{d}$ es el diámetro

() Error dado como desviación estándar. Sólo para las muestras de Carrara sin tratar, error máximo dado como semi-dispersión (max-min)/2.

TABLE V

Contact angle $\alpha$ (degrees) $\left(^{*}\right)$

\begin{tabular}{|c|c|c|c|}
\hline Treatment & Before weathering & After Artif. Weath. & After Nat. Weath. \\
\hline \multicolumn{4}{|c|}{ Carrara Marble } \\
\hline Untreated & $70 \pm 10$ & $71 \pm 7$ & $63 \pm 9$ \\
\hline sco & $84 \pm 6$ & $69 \pm 6$ & $72 \pm 6$ \\
\hline AS & $79 \pm 5$ & $90 \pm 7$ & $77 \pm 9$ \\
\hline S & $93 \pm 8$ & $61 \pm 5$ & $51 \pm 7$ \\
\hline$F$ & $80 \pm 7$ & $59 \pm 10$ & $51 \pm 10$ \\
\hline \multicolumn{4}{|c|}{ Proconnesion Marble } \\
\hline Untreated & $62 \pm 12$ & $61 \pm 10$ & $62 \pm 6$ \\
\hline sco & $78 \pm 9$ & $52 \pm 7$ & $83 \pm 7$ \\
\hline AS & $78 \pm 5$ & $91 \pm 7$ & $85 \pm 9$ \\
\hline$s$ & $90 \pm 7$ & $75 \pm 13$ & $58 \pm 6$ \\
\hline $\mathrm{F}$ & $77 \pm 6$ & $66 \pm 10$ & $72 \pm 6$ \\
\hline
\end{tabular}

$\alpha=2$ arctang $(2 \mathrm{~h} / \mathrm{d})$, where $\mathrm{h}$ is the height of the droplet and $\mathrm{d}$ its diameter.

(") Error given as standard deviation. Only for untreated Carrara samples error given as maximum of the semi-dispersion (max-min)/2. 
TABLA VI

Absorción de agua por capilaridad

\begin{tabular}{|c|c|c|c|c|c|c|}
\hline \multirow[b]{2}{*}{ Tratamiento } & \multicolumn{3}{|c|}{ C.A. $\left(10^{-4} \mathrm{~g} \cdot \mathrm{cm}^{-2} \cdot \mathrm{s}^{-1 / 2}\right)$} & \multicolumn{3}{|c|}{$M\left(10^{-3} \mathrm{~g} \cdot \mathrm{cm}^{-2}\right)$} \\
\hline & $\begin{array}{c}\text { Antes } \\
\text { desgaste }\end{array}$ & $\begin{array}{l}\text { Después } \\
\text { desgaste } \\
\text { artificial }\end{array}$ & $\begin{array}{c}\text { Después } \\
\text { desgaste } \\
\text { natural }\end{array}$ & $\begin{array}{c}\text { Antes } \\
\text { desgaste }\end{array}$ & $\begin{array}{l}\text { Después } \\
\text { desgaste } \\
\text { artificial }\end{array}$ & $\begin{array}{c}\text { Después } \\
\text { desgaste } \\
\text { natural }\end{array}$ \\
\hline \multicolumn{7}{|c|}{ Mármol Carrara } \\
\hline Sin tratar & 3,2 & 2,7 & 2,5 & 5,0 & 6,0 & 6,0 \\
\hline sco & 0,3 & 1,8 & 1,6 & 4,0 & 4,0 & 5,5 \\
\hline AS & 0,2 & 0,8 & 0,7 & 3,0 & 4,0 & 5,5 \\
\hline S & 0,2 & 0,4 & 0,4 & 2,0 & 2,0 & 2,5 \\
\hline $\mathrm{F}$ & 0,4 & 0,8 & 1,6 & 3,0 & 3,0 & 5,0 \\
\hline \multicolumn{7}{|c|}{ Mármol Proconnesio } \\
\hline Sin tratar & 0,9 & 0,7 & 1,7 & 3,0 & 3,0 & 4,0 \\
\hline sco & 0,5 & 0,9 & 1,6 & 4,0 & 4,0 & 3,9 \\
\hline AS & 0,1 & 0,3 & 1,0 & 2,0 & 2,0 & 3,0 \\
\hline S & 0,5 & 0,5 & 0,8 & 2,0 & 2,0 & 3,0 \\
\hline $\mathrm{F}$ & 0,5 & 0,6 & 1,1 & 2,0 & 3,0 & 3,2 \\
\hline
\end{tabular}

C.A. = Coeficiente de absorción por capilaridad. $M=$ Valor asintótico de agua absorbida por superficie unitaria.

TABLE VI

Water absorption by capillarity

\begin{tabular}{|c|c|c|c|c|c|c|}
\hline \multirow[b]{2}{*}{ Treatment } & \multicolumn{3}{|c|}{ C.A. $\left(10^{-4} \mathrm{~g} \cdot \mathrm{cm}^{-2} \cdot \mathrm{s}^{-1 / 2}\right)$} & \multicolumn{3}{|c|}{$M\left(10^{-3} \mathrm{~g} \cdot \mathrm{cm}^{-2}\right)$} \\
\hline & $\begin{array}{l}\text { Before } \\
\text { weath. }\end{array}$ & $\begin{array}{c}\text { After } \\
\text { Art. } \\
\text { weath. }\end{array}$ & $\begin{array}{l}\text { After } \\
\text { Nat. } \\
\text { weath. }\end{array}$ & $\begin{array}{l}\text { Before } \\
\text { weath. }\end{array}$ & $\begin{array}{c}\text { After } \\
\text { Art. } \\
\text { weath. }\end{array}$ & $\begin{array}{l}\text { After } \\
\text { Nat. } \\
\text { weath. }\end{array}$ \\
\hline \multicolumn{7}{|c|}{ Carrara Marble } \\
\hline Untreated & 3,2 & 2,7 & 2,5 & 5,0 & 6,0 & 6,0 \\
\hline $\mathrm{sco}$ & 0,3 & 1,8 & 1,6 & 4,0 & 4,0 & 5,5 \\
\hline AS & 0,2 & 0,8 & 0,7 & 3,0 & 4,0 & 5,5 \\
\hline S & 0,2 & 0,4 & 0,4 & 2,0 & 2,0 & 2,5 \\
\hline $\mathrm{F}$ & 0,4 & 0,8 & 1,6 & 3,0 & 3,0 & 5,0 \\
\hline \multicolumn{7}{|c|}{ Proconnesion Marble } \\
\hline Untreated & 0,9 & 0,7 & 1,7 & 3,0 & 3,0 & 4,0 \\
\hline SCO & 0,5 & 0,9 & 1,6 & 4,0 & 4,0 & 3,9 \\
\hline AS & 0,1 & 0,3 & 1,0 & 2,0 & 2,0 & 3,0 \\
\hline$S$ & 0,5 & 0,5 & 0,8 & 2,0 & 2,0 & 3,0 \\
\hline$F$ & 0,5 & 0,6 & 1,1 & 2,0 & 3,0 & 3,2 \\
\hline
\end{tabular}

$C A=$ Capillarity absorption coefficient. $M=$ Asymtotic value of water absorbed per unit surface. 
TABLA VII

Permeabilidad al vapor de agua $\left(g \cdot \mathrm{m}^{-2}\right.$ en $\left.24 \mathrm{~h}\right)\left(^{*}\right)$

\begin{tabular}{|c|c|c|c|}
\hline Tratamiento & Antes desgaste & Después desgaste artif. & Después desgaste nat. \\
\hline \multicolumn{4}{|c|}{ Mármol de Carrara } \\
\hline Sin tratar & $20 \pm 3$ & $20 \pm 5$ & $17 \pm 10$ \\
\hline Sco & $7 \pm 3$ & $18 \pm 5$ & $12 \pm 4$ \\
\hline AS & $4 \pm 2$ & $5 \pm 2$ & $14 \pm 5$ \\
\hline S & $2 \pm 1$ & $5 \pm 2$ & $4 \pm 2$ \\
\hline$F$ & $9 \pm 4$ & $15 \pm 6$ & $10 \pm 2$ \\
\hline \multicolumn{4}{|c|}{ Mármol Proconnesio } \\
\hline Sin tratar & $15 \pm 4$ & $16 \pm 4$ & $15 \pm 4$ \\
\hline sco & $3 \pm 2$ & $18 \pm 3$ & $17 \pm 3$ \\
\hline AS & $3 \pm 1$ & $4 \pm 1$ & $8 \pm 2$ \\
\hline S & $2 \pm 1$ & $3 \pm 2$ & $9 \pm 3$ \\
\hline $\mathrm{F}$ & $4 \pm 2$ & $6 \pm 2$ & $15 \pm 3$ \\
\hline
\end{tabular}

(") Error dado como máximo de la semi-dispersión $=(\max -\min ) / 2$.

TABLE VII

Water vapour permeability $\left(g \cdot m^{-2}\right.$ in $\left.24 h\right)\left(^{*}\right)$

\begin{tabular}{|c|c|c|c|}
\hline Treatment & Before weathering & After Artif. Weath. & After Nat. Weath. \\
\hline \multicolumn{4}{|c|}{ Carrara Marble } \\
\hline Untreated & $20 \pm 3$ & $20 \pm 5$ & $17 \pm 10$ \\
\hline sco & $7 \pm 3$ & $18 \pm 5$ & $12 \pm 4$ \\
\hline AS & $4 \pm 2$ & $5 \pm 2$ & $14 \pm 5$ \\
\hline S & $2 \pm 1$ & $5 \pm 2$ & $4 \pm 2$ \\
\hline $\mathrm{F}$ & $9 \pm 4$ & $15 \pm 6$ & $10 \pm 2$ \\
\hline \multicolumn{4}{|c|}{ Proconnesio Marble } \\
\hline Untreated & $15 \pm 4$ & $16 \pm 4$ & $15 \pm 4$ \\
\hline sco & $3 \pm 2$ & $18 \pm 3$ & $17 \pm 3$ \\
\hline AS & $3 \pm 1$ & $4 \pm 1$ & $8 \pm 2$ \\
\hline S & $2 \pm 1$ & $3 \pm 2$ & $9 \pm 3$ \\
\hline$F$ & $4 \pm 2$ & $6 \pm 2$ & $15 \pm 3$ \\
\hline
\end{tabular}

(*) Error given as maximum of the semi-dispersion $=(\max -\min ) / 2$. 
TABLA VIII

Orden de calidad de los tratamientos

\begin{tabular}{|c|c|c|c|c|c|c|c|}
\hline \multicolumn{4}{|c|}{ Mármol Carrara } & \multicolumn{4}{|c|}{ Mármol Proconnesio } \\
\hline \multicolumn{2}{|c|}{ Desgaste artificial } & \multicolumn{2}{|c|}{ Desgaste natural } & \multicolumn{2}{|c|}{ Desgaste artificial } & \multicolumn{2}{|c|}{ Desgaste natural } \\
\hline \multicolumn{8}{|c|}{ C.A. $\left(10^{-4} \mathrm{~g} \cdot \mathrm{cm}^{-2} \cdot \mathrm{s}^{-1 / 2}\right)$} \\
\hline s & $(0,4)$ & $S$ & $(0,4)$ & AS & $(0,3)$ & $S$ & $(0,8)$ \\
\hline$A S=F$ & $(0,8)$ & AS & $(0,7)$ & $S$ & $(0,5)$ & AS & $(1,0)$ \\
\hline sco & $(1,8)$ & $\mathrm{F}=\mathrm{SCO}$ & $(1,6)$ & $\mathrm{F}$ & $(0,6)$ & $F$ & $(1,1)$ \\
\hline \multirow[t]{2}{*}{ Unt. } & $(2,7)$ & Unt. & $(2,5)$ & Unt. & $(0,7)$ & sco & $(1,6)$ \\
\hline & & & & Sco & $(0,9)$ & Unt. & (1.7) \\
\hline \multicolumn{8}{|c|}{$M\left(10^{-3} \mathrm{~g} \cdot \mathrm{cm}^{-2}\right)$} \\
\hline s & $(2,0)$ & $s$ & $(2,5)$ & $S=A S$ & $(2,0)$ & $S=A S$ & $(3,0)$ \\
\hline $\mathrm{F}$ & $(3,0)$ & $\mathrm{F}$ & $(5,0)$ & $F=$ Unt. & $(3,0)$ & $F$ & $(3,2)$ \\
\hline $\mathrm{SCO}=\mathrm{AS}$ & $(4,0)$ & $S C O=A S$ & $(5,5)$ & sco & $(4,0)$ & sco & $(3,9)$ \\
\hline Unt. & $(6,0)$ & Unt. & $(6,0)$ & & & Unt. & $(4,0)$ \\
\hline \multicolumn{8}{|c|}{ Ángulo de contacto (grados) } \\
\hline AS & (90) & AS & $(77)$ & AS & (91) & AS & (85) \\
\hline Unt. & (71) & sco & (72) & $\mathrm{S}$ & (75) & Sco & (83) \\
\hline sco & (69) & Unt. & $(63)$ & $\mathrm{F}$ & (66) & $\mathrm{F}$ & (72) \\
\hline S & (61) & $F=S$ & $(51)$ & Unt. & (61) & Unt. & (62) \\
\hline $\mathrm{F}$ & $(59)$ & & & sco & (52) & S & (58) \\
\hline \multicolumn{8}{|c|}{ Permeabilidad al vapor de agua $\left(g \cdot \mathrm{m}^{-2}\right.$ en $\left.24 \mathrm{~h}\right)$} \\
\hline Unt. & (20) & Unt. & (17) & Sco & (18) & Sco & (17) \\
\hline sco & (19) & AS & (14) & Unt. & (16) & $F=U n t$. & (15) \\
\hline $\mathrm{F}$ & (15) & sco & (12) & $F$ & (6) & AS & (8) \\
\hline$A S=S$ & (5) & $\mathrm{F}$ & (10) & AS & (4) & $S$ & (9) \\
\hline & & $S$ & (4) & $S$ & (3) & & \\
\hline
\end{tabular}

Unt. $=\sin$ tratar. 
TABLE VIII

Raking order of the treatments

\begin{tabular}{|c|c|c|c|c|c|c|c|}
\hline \multicolumn{4}{|c|}{ Carrara Marble } & \multicolumn{4}{|c|}{ Proconnesion Marble } \\
\hline \multicolumn{2}{|c|}{ Artif. Weath. } & \multicolumn{2}{|c|}{ Nat. Weath. } & \multicolumn{2}{|c|}{ Artif. Weath. } & \multicolumn{2}{|c|}{ Nat. Weath. } \\
\hline \multicolumn{8}{|c|}{ C.A. $\left(10^{-4} \mathrm{~g} \cdot \mathrm{cm}^{-2} \cdot \mathrm{s}^{-1 / 2}\right)$} \\
\hline s & $(0,4)$ & $\mathrm{s}$ & $(0,4)$ & AS & $(0,3)$ & $S$ & $(0,8)$ \\
\hline$A S=F$ & $(0,8)$ & AS & $(0,7)$ & $S$ & $(0,5)$ & AS & $(1,0)$ \\
\hline sco & $(1,8)$ & $\mathrm{F}=\mathrm{SCO}$ & $(1,6)$ & $\mathrm{F}$ & $(0,6)$ & $F$ & $(1,1)$ \\
\hline \multirow[t]{2}{*}{ Unt. } & $(2,7)$ & Unt. & $(2,5)$ & Unt. & $(0,7)$ & sco & $(1,6)$ \\
\hline & & & & sco & $(0,9)$ & Unt. & $(1.7)$ \\
\hline \multicolumn{8}{|c|}{$M\left(10^{-3} \mathrm{~g} \cdot \mathrm{cm}^{-2}\right)$} \\
\hline S & $(2,0)$ & S & $(2,5)$ & $S=A S$ & $(2,0)$ & $S=A S$ & $(3,0)$ \\
\hline $\mathrm{F}$ & $(3,0)$ & $\mathrm{F}$ & $(5,0)$ & $\mathrm{F}=$ Unt. & $(3,0)$ & $\mathrm{F}$ & $(3,2)$ \\
\hline$S C O=A S$ & $(4,0)$ & $S C O=A S$ & $(5,5)$ & sco & $(4,0)$ & sco & $(3,9)$ \\
\hline Unt. & $(6,0)$ & Unt. & $(6,0)$ & & & Unt. & $(4,0)$ \\
\hline \multicolumn{8}{|c|}{ Contact Angle (degrees) } \\
\hline AS & (90) & AS & $(77)$ & AS & (91) & AS & (85) \\
\hline Unt. & (71) & sco & (72) & $S$ & (75) & Sco & (83) \\
\hline Sco & (69) & Unt. & (63) & $\mathrm{F}$ & (66) & $\mathrm{F}$ & (72) \\
\hline S & (61) & $F=S$ & (51) & Unt. & (61) & Unt. & (62) \\
\hline $\mathrm{F}$ & (59) & & & sco & (52) & $S$ & (58) \\
\hline \multicolumn{8}{|c|}{ Water Vapour Permeability $\left(\mathrm{g} \cdot \mathrm{m}^{-2}\right.$ in $\left.24 \mathrm{~h}\right)$} \\
\hline Unt. & (20) & Unt. & (17) & sco & (18) & Sco & (17) \\
\hline sco & (19) & AS & (14) & Unt. & (16) & $\mathrm{F}=$ Unt. & (15) \\
\hline $\mathrm{F}$ & (15) & Sco & $(12)$ & $\mathrm{F}$ & (6) & AS & (8) \\
\hline \multirow[t]{2}{*}{$A S=S$} & (5) & $F$ & (10) & AS & (4) & $S$ & (9) \\
\hline & & $S$ & (4) & $S$ & (3) & & \\
\hline
\end{tabular}

Unt. = untreated. 
Cuando se evalúan globalmente los resultados de todos los parámetros medidos después de las dos exposiciones, la conducta más satisfactoria es siempre la mostrada por los tratamientos $S$ y AS, mientras que F y SCO muestran una baja duración. Sin embargo las muestras tratadas con AS (y también con SCO), cuando se exponen en el exterior, se vuelven más polvorientas que las otras. La remoción del depósito es difícil y, en todo caso, el color resultante ha cambiado mucho respecto del inicial.

En ambos tratamientos AS y SCO está presente un copolímero acrílico. Parece razonable atribuir a esa resina la propiedad de atracción y retención del polvo.

Especialmente en el caso de monumentos y esculturas, expuestos al exterior, la propiedad de atraer y retener el polvo representa un importante inconveniente que induce a una evaluación negativa del tratamiento, aunque otras propiedades, como aquéllas relacionadas con el agua, sean buenas.

Tomando en cuenta la consideración antes mencionada, el tratamiento $S$ puede ser juzgado como el más efectivo entre aquéllos examinados.

Llegando a la comparación entre los dos sistemas de envejecimiento, es posible decir que ambos producen efectos bastante parecidos, aunque el desgaste natural es un poco más duro.

La única diferencia básica es debida a la presencia del polvo en el ambiente natural; químicamente agresivo y rico de partículas carbonosas en las zonas urbanas contaminadas.

Por otro lado, el desgaste artificial produce, en 33 días, resultados parecidos a aquéllos dados después de dos años de exposición natural.

Esta experiencia resulta al confirmar la utilidad de las simulaciones de laboratorio, pero subraya la necesidad de mejorarlas agregando polvo, en especial las partículas suspendidas a los factores de los ciclos artificiales.

Es sin embargo de una cierta dificultad reproducir las condiciones que llevan a la adhesión de las partículas suspendidas a la superficie de la piedra hasta la formación de la costra negra, que es tan común encontrar en los monumentos en nuestra área (Foto 4). Una posibilidad puede ser dada por la cámara climática planeada para conseguir la entrada de cantidades controladas de partículas y su captura por la superficie de las muestras de ensayo.

Este tipo de cámara está siendo proyectada por el Instituto Central del Restauro de Roma (Laurenzi Tabasso, Marabelli, 1988).
When comprehensively evaluating the results of all the measured parameters after the two exposures, the most satisfactory behaviour is always given by the $S$ and the AS treatments, while $F$ and SCO show a lower durability. However, the samples treated with AS (and SCO as well) when exposed outdoors become much dustier than the other ones. The removal of deposit is difficult and, in any case, the resulting colour has changed much more in respect to the initial one.

In both the AS and SCO treatments an acrylic copolymer is present and it seems reasonable to ascribe to that resin the property of attracting and retaining dust.

Especially in the case of monuments and sculptures exposed outdoors the property of attracting and retaining dust represents an important drawback which results in a negative evaluation of the treatment even if other properties, such as those related to water, are good.

Taking into account the above consideration, the $S$ treatment can be judged the most effective among those tested.

Coming to the comparison between the two ageing systems, it is possible to say that they produced rather similar effects, even if natural weathering was slightly more severe.

The only serious, basic difference is due to the presence of dust in the natural environment, chemically aggressive and rich in carbonaceous matter in urban polluted areas.

On the other hand, artificial weathering produced in 33 days results similar to those given by two years of natural exposure.

This experimental result confirms the usefulness of the laboratory simulations but stresses the necessity to improve them by adding the dust, particularly the suspended particulated matter, to the factors of artificial cycles.

It is certainly difficult to reproduce the conditions which bring about the adhesion of s.p.m. on the stone surface up to the formation of the black crust which is so frequently found on monuments in our climate (Phot. 4). One possibility may be given by a climatic chamber planned in order to have the inlet of controlled amounts of particulate matter and its capture by the surface of the test samples.

Such a type of chamber is beeing planned by the Central Institute for Restoration in Rome (Laurenzi Tabasso, Marabelli, 1988). 


\section{AGRADECIMIENTOS}

Las autoras desean agradecer al doctor U. Santamaría y al señor G. Venturi por haber llevado a cabo las mediciones porosimétricas.

\section{AKNOWLEDGEMENTS}

Authors wish to thank Mr. U. Santamaria and Mr. G. Venturi for having carried out the porosimetric measurementc

\section{BIBLIOGRAFIA BIBLIOGRAPHY}

ASTM, 1968. Specifying Color by the Munsell System. ASTM D-1535-1968, Am. Soc. for Testing Materials.

D. BROCCO, A. GIOVAGNOLI, M. LAURENZI TABASSO, M. MARABELLI, R. TAPPA, R. POLESI, (1988). "Air pollution in Rome and its role in the deterioration of porous building materials", in Durability of Building Materials, 5, Amsterdam, pp. 393-408.

M. COSA, P.G. TUPINI, (1988). "Dati significativi sull'inquinamento atmosferico nel centro storico", in // Tritone Restaurato, a cura di M. L. Cardilli, Ed. Quasar, Roma, pp. 63-66.

V. FASSINA, L. LAZZARINI, M. LAURENZI TABASSO, A. M. MECCHI, (1987): "Protective treatments for the reliefs of the Arconi di S. Marco in Venice: Laboratory evaluation, in Durability of Building Materials, 5, Amsterdam, pp. 167-181.

J. L. HEIMAN, (1988). "How useful is short-term testing in the assessment of the long term durability of sandstone?", Proc. of the $V$ th Int. Congress on Deterioration and Conservation of Stone, Torun, pp. 356-366.

L. LAZZARINI, M. MARIOTTINI, (1987). "La provenienza dei marmi cristallini usati in antico: un nuovo contributo al rapporto Calcite/Dolomite", in Bollettino d'Arte "Materiali Lapidei", Vol. 1, Supplemento n. 41, Roma, pp. 69-72.

L. LAZZARINI, G. MOSCCINI, B. M. STIEVANO, (1980): "A contribution to the identification of Italian, Greek and Anatolian marbles through a petrological study and the evaluation of $\mathrm{Ca} / \mathrm{Sr}$ ratio", in Archaeometry, 22, 2, pp. 173-183.

M. LAURENZI TABASSO, M. MARABELLI, (1988): "Progetto di una camera climatica per la formazione di croste nere su campioni lapidei e metallici", Rapporto interno ICR, Roma.

Doc. NORMAL 11/85, (1985). Assorbimento di acqua per capillarita'-Coefficiente di assorbimento capillare, CNR-ICR, Roma.

Doc. NORMAL 21/85, (1985). Misura della permeabilita' al vapor d'acqua, CNR-ICR, Roma.

O. Nonfarmale, (1975). "A method of consolidation and restoration of decayed sandstones", in The Conservation of Stone I, Proc of the Int. Symp., Bologna, pp. 401-405

K. Zehder, A. Arnold, (1988). "New experiments on salt crystallization", in Proc. of the VIth Int. Congress on Deterioration and Conservation of Stone, Torun, pp. 320-329.

\section{publicación del ICCET/CSIC}

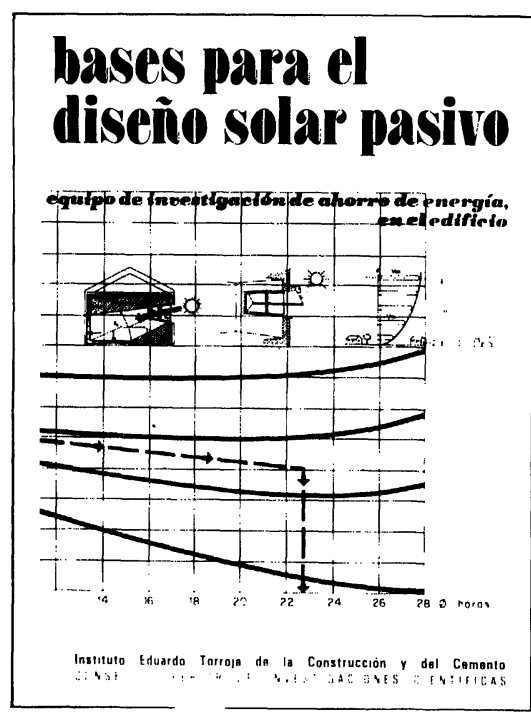

Equipo de Ahorro de Energia en el edificio

Dirección y coordinación: Arturo Garcia Arroyo

M. ${ }^{\text {a José Escorihuela }}$ José Luis Esteban José Miguel Frutos Manuel Olaya Bernardo Torroja
Las dificultades de suministro $y$ el alto coste de los productos energéticos convencionales han despertado la atención de los usuarios, técnicos $\mathrm{e}$ industriales de la edificación hacia los procedimientos y sistemas en que se basa el aprovechamiento de otras fuentes alternativas de encria principalmente la solar. olar. Esto ha generado un rapido desarrollo industrial $y$ comercial que, en opinión de los autores de este libro, arrastran los siguientes defectos: un mimético tecnologismo respecto de los sistemas convencionales que violenta las peculiaridades de la energía solar (baja densidad $y$ variabilidad on el tiempol y una selectividad en la aplicación de los sistemas y procedimientos pasivos dando origen a un ecumenismo arquitectónico solar, al margen de las condiciones climáticas y funcionales especificas de cada caso y lugar.

En este libro, utilizando criterios y metodologia pedagógicos, se dan los fundamentos e instru. mentos teórico-prácticos necesarios para el planteamiento de todo proyecto arquitectónico solar pasivo, de acuerdo con los principios éticos y económicos de conservación y ahorro de energía. Es decir: respeto de los presupuestos bioclimáticos, búsqueda de la máxima captación y acumulación de la radiación solar, y esmero en el aislamiento térmico de los cerramientos.

Un volumen encuadernado en cartulina ibiza plastificada, a cinco colores, de $16 \times 23 \mathrm{~cm}$, compuesto de 216 páginas, 217 figuras, 87 gráficos, 19 tablas y 10 cuadros. 